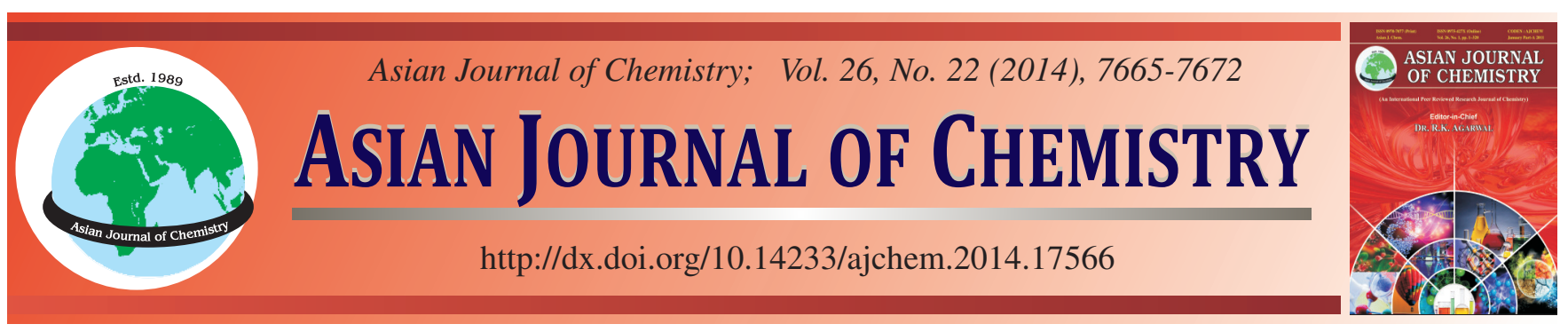

\title{
Synthesis of Phenylcarbamic Acid and 2-[2-Oxo-3-(4-substituted phenylimino)- indolin-1-yl]acetohydrazide Derivatives as Promising Antifungal Agents
}

\author{
Zainab Al Marhoon ${ }^{1}$, Ahmed Abdel-Megeed ${ }^{2,3,{ }^{*}}$, Essam N. Sholkamy ${ }^{2}$, M. Rafiq H. Siddiqui ${ }^{1}$ and Ayman El-Faham ${ }^{1,4, *}$
}

${ }^{1}$ Department of Chemistry, College of Science, King Saud University, P.O. Box 2455, Riyadh 11451, Saudi Arabia

${ }^{2}$ Department of Botany and Microbiology, College of Science, King Saud University, P.O. Box 2455, Riyadh 11451, Saudi Arabia

${ }^{3}$ Department of Plant Protection, Faculty of Agriculture, Saba Basha, Alexandria University, Alexandria, Egypt

${ }^{4}$ Department of Chemistry, Faculty of Science, Alexandria University, P.O. Box 426, Ibrahimia 21321, Alexandria, Egypt

*Corresponding author: E-mail: aamahmoud@ksu.edu.sa

\begin{abstract}
Four phenylcarbamic acid methyl ester derivatives were prepared by oxidative transformation of isatin's Schiff bases (Baeyer-Villiger oxidation) under conventional heating as well as microwave irradiation. The ester derivatives were treated with hydrazine hydrate under microwave irradiation to afford the hydrazide derivatives in less reaction time and good yield. 2-(2-Oxo-3-(4-substituted phenylimino)indolin1-yl)acetohydrazide derivatives were also prepared from isatin's Schiff bases under microwave irradiation in less reaction time and high yield and purity. The synthesized compounds exhibited promising antifungal activity particularly against the human pathogenic Candida albicans. While they did not show any activity against the Streptococcus pyogenes, Staphylococcus aureus, Salmonella typhi, Klebsiella pneumoniae, Pseudomonas aeruginosa, Aspergillus flavus and Aspergillus niger.
\end{abstract}

Keywords: Isatin Schiff bases, Microwave irradiation, Phenylcarbamic acid hydrazide, Candida albicans, Antimicrobial activity.

\section{INTRODUCTION}

Candida albicans is a diploid fungus that grows both as yeast and filamentous cells and a causal agent of opportunisticoral and genital infections in humans ${ }^{1}$. Systemic fungal infections (fungemias) including those by $C$. albicans have emerged as important causes of morbidity and mortality in immuno compromised patients (e. g., AIDS, cancer chemotherapy, organ or bone marrow transplantation). C. albicans biofilms may form on the surface of implantable medical devices. In addition, hospital-acquired infections by $C$. albicans have become a cause of major health concerns ${ }^{2} . C$. albicans is commensally and a constituent of the normal gut flora comprising microorganisms that live in the human mouth and gastrointestinal tract. C. albicans lives in $80 \%$ of the human population without causing harmful effects, although overgrowth of the fungus results in candidiasis (candidosis) ${ }^{3}$. Candidiasis is often observed in immunocompromised individuals such as HIV-infected patients. A common form of candidiasis restricted to the mucosal membranes in mouth or vagina is thrush, which is usually easily cured in people who are not immunocompromised ${ }^{1}$. For example, higher prevalence of colonization of $C$. albicans was reported in young individuals with tongue piercing, in comparison to unpierced matched individuals ${ }^{4}$. To infect host tissue, the usual unicellular yeast-like form of $C$. albicans reacts to environmental cues and switches into an invasive, multicellular filamentous form, a phenomenon called dimorphism.

It is well known that $C$. albicans cell surfaces are negatively charged. Therefore, adsorption onto the negatively charged cell surface is expected to be enhanced with the increasing charge density of the cationic biocides. Therefore, it is reasonable to assume that the adsorption onto the fungal cell surface is much more enhanced for polymers than for model compounds $\mathrm{s}^{5-8}$. A similar situation can also be expected in binding to the cytoplasmic membrane, because there are many negatively charged species present in the cytoplasmic membrane, such as acidic phospholipids and some membrane proteins ${ }^{9-11}$. The disruption of the cytoplasmic membrane is a result of the interaction of the bound polymers with the membrane disruption and, therefore, is expected to be facilitated with increasing amounts of the bound compound.

The development of simple, facile and efficient synthetic methods for the synthesis of biologically active compounds from readily available reagents is one of the major challenges in organic synthesis ${ }^{12}$. Baeyer-Villiger oxidation is a very old and valuable chemical transformation ${ }^{12-27}$. The Baeyer-Villiger reaction $^{12}$, in which a ketone is converted into an ester or 
lactone upon treatment with a peracid, is a valuable reaction because of the importance of the products, the uniqueness of the transformation and the difficulty of accomplishing it by other means ${ }^{28-30}$.

\section{EXPERIMENTAL}

Solvents used were of HPLC reagent grade. Melting points were determined with a Mel-Temp apparatus and are uncorrected. Fourier transform infrared spectroscopy (FTIR) Spectra was recorded on Nicolet 560. Nuclear magnetic resonance spectra $\left({ }^{1} \mathrm{H}\right.$ NMR and ${ }^{13} \mathrm{C}$ NMR spectra) were recorded on a JOEL $400 \mathrm{MHz}$ spectrometer with chemical shift values reported in $\delta$ units ( $\mathrm{ppm}$ ) relative to an internal standard. The microwave irradiation employed a multimode reactor (Synthos 3000, Aton Paar GmbH and $1400 \mathrm{~W}$ maximum magnetron). Elemental analyses were performed on Perkin-Elmer 2400 elemental analyzer and the values found were within $\pm 0.3 \%$ of the theoretical values. Follow-up of the reactions and checks of the purity of the compounds was done by TLC on silica gel-protected aluminum sheets (Type 60 GF254, Merck) and the spots were detected by exposure to UV-lamp at $\lambda 254 \mathrm{~nm}$ for a few seconds. The compounds were named using ChemDraw Ultra version 11, Cambridge Soft Corporation (Cambridge, MA, USA).

\section{General procedure for synthesis of $2 \mathrm{a}-\mathrm{d}$}

Conventional heating (A): A mixture of indole-2,3-dione $(0.01 \mathrm{~mol})$ and 4 -substituted aniline $(0.01 \mathrm{~mol})$ in absolute ethanol $(20 \mathrm{~mL})$ was refluxed for $4 \mathrm{~h}$ in the presence of 2-3 drops of glacial acetic acid. After cooling to room temperature, the solid product was filtered and recrystallized from $96 \%$ ethanol.

Microwave method (B): A multimode reactor (Anton Paar GmbH Synthos 3000, 1,400 W maximum magnetron) was used. The initial step was conducted with a 2-Teflon vessels rotor (MF 100). The initial step was conducted with 4-Teflon vessels rotor (MF 100) that allow processing four reactions under the same conditions. Each vessel has indole-2,3-dione mixed with different amine in ethanol. The individual vessels were placed in the corresponding rotor, fixed by screwing down the upper rotor place and finally the rotor was closed with a protective hood. The vessels were heated for $1 \mathrm{~min}$ at $80^{\circ} \mathrm{C}$ and held at the same temperature for a further 1 min (under $0.2 / \mathrm{s}$ bar pressure, $400 \mathrm{~W}$ ). Cooling was accomplished by a fan (for $5 \mathrm{~min}$ ). The desired product was collected, dried and then recrystallized from ethanol.

3-Phenylimino-1,3-dihydro-indol-2-one (2a): The product was obtained as a yellow crystal, m.p.: $218^{\circ} \mathrm{C}$; yield: $87 \%(\operatorname{method} \mathrm{A}) ; 90 \%(\operatorname{method} \mathrm{B})\left(\right.$ lit. $^{44}$ m.p. $183{ }^{\circ} \mathrm{C}$, yield $89 \%)$. IR (KBr, $\left.v_{\max }, \mathrm{cm}^{-1}\right): 3257(\mathrm{NH}), 1720(\mathrm{C}=\mathrm{O}), 1610$ $(\mathrm{C}=\mathrm{N}) .{ }^{1} \mathrm{H}-\mathrm{NMR}\left(\mathrm{DMSO}-d_{6}\right) \delta(\mathrm{ppm}) 6.31(\mathrm{~d}, J=7.68 \mathrm{~Hz}$, $1 \mathrm{H}), 6.69(\mathrm{t}, J=7.71,1 \mathrm{H}), 6.88(\mathrm{~d}, J=7.70 \mathrm{~Hz}, 1 \mathrm{H}), 6.96(\mathrm{~d}$, $J=8.07 \mathrm{~Hz}, 2 \mathrm{H}), 7.24(\mathrm{t}, J=8.00,1 \mathrm{H}), 7.32(\mathrm{t}, J=7.68 \mathrm{~Hz}$, $1 \mathrm{H}), 7.45(\mathrm{t}, J=8.08 \mathrm{~Hz}, 2 \mathrm{H}), 10.99(\mathrm{~s}, 1 \mathrm{H}, \mathrm{NH}) ;{ }^{13} \mathrm{C} \mathrm{NMR}$ $\left(\mathrm{DMSO}-d_{6}\right): \delta$ (ppm) 111.2, 115.3, 116.8, 121.3, 124.6, 125.0, 129.2,134.1, 146.6, 150.2, 154.6, 163.1.

3-p-Tolylimino-1,3-dihydro-indol-2-one (2b): The product was obtained as an orange crystal, m.p. : $222^{\circ} \mathrm{C}$; yield: $56 \%(\operatorname{method} \mathrm{A}) ; 80 \%(\operatorname{method} \mathrm{B})\left(\right.$ lit. ${ }^{47}$ m.p. $222{ }^{\circ} \mathrm{C}$, yield $66 \%)$ IR (KBr, $\left.v_{\max }, \mathrm{cm}^{-1}\right): 3448(\mathrm{NH}), 1742,1720(\mathrm{C}=\mathrm{O})$,
$1610(\mathrm{C}=\mathrm{N}) .{ }^{1} \mathrm{H}-\mathrm{NMR}\left(\mathrm{DMSO}-d_{6}\right): \delta(\mathrm{ppm}) 2.40\left(\mathrm{~s}, \mathrm{CH}_{3}, 3 \mathrm{H}\right)$, $6.74(\mathrm{~d}, J=7.7 \mathrm{~Hz}, 1 \mathrm{H}), 6.80(\mathrm{t}, J=7.7 \mathrm{~Hz}, 1 \mathrm{H}), 6.93(\mathrm{~d}, J=$ $7.72 \mathrm{~Hz}, 1 \mathrm{H},), 6.95(\mathrm{~d}, J=8.04,2 \mathrm{H}), 7.23(\mathrm{~d}, J=8.07 \mathrm{~Hz}$, 2H), 7.29 (t, $J=7.73 \mathrm{~Hz}, 1 \mathrm{H}), 9.71(\mathrm{~s}, 1 \mathrm{H}, \mathrm{NH}) ;{ }^{13} \mathrm{C}-\mathrm{NMR}$ (DMSO- $d_{6}$ ): $\delta$ (ppm) 20.4, 111.3, 115.5, 117.6, 122.0, 125.4, $129.3,133.57,134.7,145.2,146.6,153.9,165.2$.

3-(4-Bromo-phenylimino)-1,3-dihydroindol-2-one (2c): The product was obtained as a yellow crystal, m.p.: 270 ${ }^{\circ} \mathrm{C}$; yield: $96 \%(\operatorname{method} \mathrm{A}) ; 92 \%(\operatorname{method} \mathrm{B})\left(\right.$ lit. ${ }^{47}$ m.p. 242 ${ }^{\circ} \mathrm{C}$, yield $87 \%$ ) IR (KBr, $\left.v_{\max }, \mathrm{cm}^{-1}\right): 3416(\mathrm{NH}), 1740(\mathrm{C}=\mathrm{O})$, $1614(\mathrm{C}=\mathrm{N}) .{ }^{1} \mathrm{H}-\mathrm{NMR}\left(\mathrm{DMSO}-d_{6}\right): \delta(\mathrm{ppm}) 6.43(\mathrm{~d}, J=7.68$ $\mathrm{Hz}, 1 \mathrm{H}), 6.78$ (t, $J=7.68,1 \mathrm{H}), 6.90(\mathrm{~d}, J=7.98 \mathrm{~Hz}, 1 \mathrm{H}), 6.98$ $(\mathrm{d}, J=8.22 \mathrm{~Hz}, 2 \mathrm{H}), 7.37(\mathrm{t}, J=7.71 \mathrm{~Hz}, 1 \mathrm{H}),, 7.65(\mathrm{~d}, J=$ $8.25 \mathrm{~Hz}, 2 \mathrm{H}), 11.02(\mathrm{~s}, \mathrm{H}, \mathrm{NH}) ;{ }^{13} \mathrm{C}-\mathrm{NMR}\left(\mathrm{DMSO}-d_{6}\right): \delta(\mathrm{ppm})$ 111.8, 115.7, 117.3, 119.9, 122.06, 125.6, 132.6, 134.9, 147.3, $149.7,155.5,163.5$.

3-(4-Methoxy-phenylimino)-1,3-dihydro-indol-2-one (2d): The product was obtained as a dark yellow crystal, m.p.: $230{ }^{\circ} \mathrm{C}$; yield: $89 \%(\operatorname{method} \mathrm{A}) ; 90 \%(\operatorname{method} \mathrm{B})\left(\right.$ lit. ${ }^{47} \mathrm{~m} . \mathrm{p}$. $226{ }^{\circ} \mathrm{C}$; yield $66 \%$ ). IR ( $\left.\mathrm{KBr}, v_{\max }, \mathrm{cm}^{-1}\right): 3229(\mathrm{NH}), 1738$ $(\mathrm{C}=\mathrm{O}), 1612(\mathrm{C}=\mathrm{N}) .{ }^{1} \mathrm{H}-\mathrm{NMR}\left(\mathrm{DMSO}-d_{6}\right): \delta(\mathrm{ppm}) 3.79(\mathrm{~s}$, $\left.\mathrm{OCH}_{3}, 3 \mathrm{H}\right), 6.64(\mathrm{~d}, J=7.7 \mathrm{~Hz}, 1 \mathrm{H}), 6.75$ (t, $\left.J=8.07 \mathrm{~Hz}, 1 \mathrm{H}\right)$, $6.89(\mathrm{~d}, J=7.70 \mathrm{~Hz}, 1 \mathrm{H}), 6.98(\mathrm{~d}, J=8.40 \mathrm{~Hz}, 2 \mathrm{H}), 7.04$ (d, $J=8.40 \mathrm{~Hz}, 2 \mathrm{H}), 7.33(\mathrm{t}, J=8.07 \mathrm{~Hz}, 1 \mathrm{H}), 10.97(\mathrm{~s}, \mathrm{H}, \mathrm{NH})$; ${ }^{13} \mathrm{C}-\mathrm{NMR}\left(\mathrm{DMSO}-d_{6}\right): \delta(\mathrm{ppm}) 54.8,111.0,112.9,114.2$, 115.3, 119.0, 121.2, 124.5, 133.7, 146.3, 154.0, 156.6, 163.2.

General procedure for synthesis of 3a-d using microwave irradiation ${ }^{50}$ : $\mathrm{A}$ mixture of $\mathbf{2 a - d}(5 \mathrm{mmol}), \mathrm{K}_{2} \mathrm{CO}_{3}$ $(6 \mathrm{mmol})$ and ethyl chloroacetate $(6 \mathrm{mmol})$ in acetone $(10 \mathrm{~mL})$ was irradiated under MWI at $60^{\circ} \mathrm{C} / 600$ Watts for $10 \mathrm{~min}$. The solvent was removed under vacuum and the residue washed with water and dried. The crude products $(0.1 \mathrm{~mol})$ were subjected to react with $\mathrm{NH}_{2} \mathrm{NH}_{2}(99 \%, 0.4 \mathrm{~mol})$ in methanol under microwave irradiation at $60{ }^{\circ} \mathrm{C} / 400$ Watts for $2 \mathrm{~min}$. The solid product was filtered and washed with cold methanol to afford the pure product 3a-d.

2-[2-Oxo-3-(phenylimino)indolin-1-yl]acetohydrazide (3a): The product was obtained as a yellow powder, m.p.: 214$216{ }^{\circ} \mathrm{C}$; yield $68 \%$ : IR( $\left.\mathrm{KBr}, v_{\max }, \mathrm{cm}^{-1}\right) 3314,3133(\mathrm{NH})$, 1678, $1651(\mathrm{C}=\mathrm{O}), 1614(\mathrm{C}=\mathrm{N}) .{ }^{1} \mathrm{H}-\mathrm{NMR}\left(\mathrm{DMSO}-d_{6}: \delta(\mathrm{ppm})\right.$ 4.34 (s, 2H, $\left.\mathrm{NC}_{2} \mathrm{COO}\right), 6.90$ (d, $\left.J=7.68 \mathrm{~Hz}, 2 \mathrm{H}\right), 7.03$ (t, $J$ $=7.68 \mathrm{~Hz}, 1 \mathrm{H}), 7.01-7.05(\mathrm{~m}, 2 \mathrm{H}, \mathrm{Ar}), 7.17-7.20(\mathrm{~m}, 2 \mathrm{H}, \mathrm{Ar})$, 7.41 (d, $J=7.68 \mathrm{~Hz}, 2 \mathrm{H}), 9.40$ (s, NH), 9.67 (d, NH), 10.43 $(\mathrm{d}, \mathrm{NH}) ;{ }^{13} \mathrm{C}$ NMR (DMSO- $\left.d_{6}\right): \delta(\mathrm{ppm}) 39.6\left(\mathrm{NCH}_{2} \mathrm{CO}\right)$, 108.2, 116.5, 120.8, 121.2,124.6,126.1,138.8, 160.1, 165.3. Anal. Calcd for $\mathrm{C}_{16} \mathrm{H}_{14} \mathrm{~N}_{4} \mathrm{O}_{2}$ : C, 65.30; H, 4.79; N, 19.04 . Found: C, 65.55; H, 4.98; N, 19.32.

2-[2-Oxo-3-(p-tolylimino)indolin-1-yl]acetohydrazide (3b): The product was obtained as a yellow powder, m.p.: 214$216{ }^{\circ} \mathrm{C}$; yield $81 \%$ : IR $\left(\mathrm{KBr}, v_{\max }, \mathrm{cm}^{-1}\right)$ : 3310, $3135(\mathrm{NH})$, $1679,1653(\mathrm{C}=\mathrm{O}), 1589(\mathrm{C}=\mathrm{N}){ }^{1} \mathrm{H}-\mathrm{NMR}\left(\mathrm{DMSO}-d_{6}\right): \delta(\mathrm{ppm})$ 2.50 (s, 3H, $\left.\mathrm{C}_{6} \mathrm{H}_{4} \mathrm{CH}_{3}\right), 4.34$ (s, $\left.2 \mathrm{H}, \mathrm{NCH}_{2} \mathrm{CO}\right), 6.90$ (d, $J=$ 8.04 Hz, 2H), 7.01-7.07 (m, 2H, Ar), 7.17-7.23 (m, 2H, Ar), $7.41(\mathrm{~d}, J=7.32 \mathrm{~Hz}, 2 \mathrm{H}) ;{ }^{13} \mathrm{C}-\mathrm{NMR}$ (DMSO- $\left.d_{6}\right): \delta(\mathrm{ppm})$ 39.1, 108.3, 116.61, 120.9, 121.4, 126.3, 138.9, 158.5, 160.2, 165.5. Anal. Calcd for $\mathrm{C}_{17} \mathrm{H}_{16} \mathrm{~N}_{4} \mathrm{O}_{2}$ : C, 66.22; H, 5.23; N, 18.17 . Found: C, 66.37; H, 5.40; N, 18.32.

2-[3-(4-Bromophenylimino)-2-oxoindolin-1-yl]acetohydrazide $(\mathbf{3 c})$ : The product was obtained as a yellow 
powder, m.p.: 209-210 ${ }^{\circ} \mathrm{C}$; yield $78 \%$ : IR $\left(\mathrm{KBr}, \mathrm{v}_{\max }, \mathrm{cm}^{-1}\right)$ 3316, $3132(\mathrm{NH}), 1679,1653(\mathrm{C}=\mathrm{O}), 1586(\mathrm{C}=\mathrm{N}) .{ }^{1} \mathrm{H}-\mathrm{NMR}$ (DMSO- $\left.d_{6}\right): \delta(\mathrm{ppm}) 4.34$ (s, $\left.2 \mathrm{H}, \mathrm{NC}_{2} \mathrm{CO}\right), 6.90(\mathrm{~d}, J=8.00$, 2H), 7.01-7.06 (m, 2H, Ar), 7.17-7.22 (m, 2H, Ar), 7.41 (d, J $=7.32 \mathrm{~Hz}, 2 \mathrm{H}), 9.41(\mathrm{~s}, \mathrm{NH}), 9.69(\mathrm{~d}, \mathrm{NH}), 10.44(\mathrm{~d}, \mathrm{NH})$; ${ }^{13} \mathrm{C}-\mathrm{NMR}$ (DMSO- $d_{6}$ ): $\delta$ (ppm) 39.0, 108.2, 116.5, 120.8, 121.23, 124.6, 126.2, 138.8, 160.1, 165.32. Anal. Calcd for $\mathrm{C}_{16} \mathrm{H}_{13} \mathrm{~N}_{4} \mathrm{O}_{2} \mathrm{Br}$ : C, 51.49; H, 3.51; N, 15.01. Found: C, 51.61; $\mathrm{H}, 3.60 ; \mathrm{N}, 15.35$

2-[3-(4-Methoxyphenylimino)-2-oxoindolin-1-yl]acetohydrazide (3d): The product was obtained as a yellow powder, m.p.:214-216 ${ }^{\circ} \mathrm{C}$; yield $64 \%$. IR $\left(\mathrm{KBr}, v_{\max }, \mathrm{cm}^{-1}\right)$ : 3311, $3133(\mathrm{NH}), 1677,1652(\mathrm{C}=\mathrm{O}), 1587(\mathrm{C}=\mathrm{N}) .{ }^{1} \mathrm{H}-\mathrm{NMR}$ $\left(\mathrm{DMSO}-d_{6}\right): \delta$ (ppm) $3.36\left(\mathrm{~s}, 3 \mathrm{H}, \mathrm{C}_{6} \mathrm{H}_{4} \mathrm{OCH}_{3}\right), 4.34(\mathrm{~s}, 2 \mathrm{H}$, $\left.\mathrm{NC}_{2} \mathrm{CO}\right), 6.90$ (d, $\left.J=8.04 \mathrm{~Hz}, 2 \mathrm{H}\right), 7.01-7.03$ (m, 2H, Ar), 7.17-7.22 (m, 2H, Ar), $7.41(\mathrm{~d}, J=7.92 \mathrm{~Hz}, 2 \mathrm{H}), 9.40$ (s, $\mathrm{NH}), 9.68(\mathrm{~d}, \mathrm{NH}), 10.44(\mathrm{~d}, \mathrm{NH}) ;{ }^{13} \mathrm{C}-\mathrm{NMR}\left(\mathrm{DMSO}-d_{6}\right): \delta$ (ppm) 39.5, 53.6, 108.3, 115.7, 116.6, 121.0, 121.4, 121.8, 124.7, 126.3, 127.8, 138.9, 160.2, 165.5, 165.71. Anal. Calcd for $\mathrm{C}_{17} \mathrm{H}_{16} \mathrm{~N}_{4} \mathrm{O}_{3}: \mathrm{C}, 62.95 ; \mathrm{H}, 4.97 ; \mathrm{N}, 17.27$. Found: C, 63.17; $\mathrm{H}, 5.05 ; \mathrm{N}, 17.53$.

General procedure for synthesis of [2-arylcarbamoyl phenyl]carbamic acid methyl ester (4a-d)

Conventional method $(\mathbf{A})^{43}$ : Solution of $m$-chloroperbenzoic acid ( $m$-CPBA, $2.4 \mathrm{mmol})$ in the methanol $(25 \mathrm{~mL})$ was added dropwise to a vigorously stirred solution of the imine (3a-d) $(2 \mathrm{mmol})$ in $\mathrm{CH}_{3} \mathrm{OH}(25 \mathrm{~mL})$ at $0{ }^{\circ} \mathrm{C}$. After $3 \mathrm{~h}$ at $0{ }^{\circ} \mathrm{C}$, the reaction mixture was allowed to warm up to room temperature and continued stirring for $24 \mathrm{~h}$. The solvent was removed and the crude product was recrystallized from methanol.

Microwave method (B): A solution of the imine (3a-d) $(2 \mathrm{mmol})$ and $m$-CPBA $(2.4 \mathrm{mmol})$ in $\mathrm{CH}_{3} \mathrm{OH}(5 \mathrm{~mL})$ was microwave irradiated for $5 \mathrm{~min}$ at $80{ }^{\circ} \mathrm{C} / 600 \mathrm{~W}$. The crude product washed with cooled methanol to afford the pure products 4a-d.

Methyl-2-(phenylcarbamoyl)phenylcarbamate (4a): The product was obtained as a white crystal, m.p.:176-178 ${ }^{\circ} \mathrm{C}$; yield \%: $50 \%(\operatorname{method} \mathrm{A}) ; 78 \%(\operatorname{method} \mathrm{B}) .\left(\right.$ lit. $^{43}$ m.p. $183-$ $184{ }^{\circ} \mathrm{C}$; yield $\left.83 \%\right)$. IR ( $\left.\mathrm{KBr}, \mathrm{v}_{\max }, \mathrm{cm}^{-1}\right): 3244,3200(\mathrm{NH})$, $1731,1652(\mathrm{C}=\mathrm{O}) .{ }^{1} \mathrm{H}-\mathrm{NMR}\left(\mathrm{DMSO}-d_{6}\right): \delta(\mathrm{ppm}) 3.65(\mathrm{~s}, 3 \mathrm{H}$, $\left.\mathrm{COOC}_{3}\right), 7.13(\mathrm{t}, J=7.71 \mathrm{~Hz}, 1 \mathrm{H}), 7.19(\mathrm{t}, J=7.68 \mathrm{~Hz}, 1 \mathrm{H})$, $7.36(\mathrm{t}, J=8.04 \mathrm{~Hz}, 2 \mathrm{H}), 7.54(\mathrm{t}, J=8.79 \mathrm{~Hz}, 1 \mathrm{H}), 7.71(\mathrm{~d}, J$ $=8.04 \mathrm{~Hz}, 2 \mathrm{H}), 7.81(\mathrm{~d}, J=8.07 \mathrm{~Hz}, 1 \mathrm{H}), 8.05(\mathrm{~d}, J=8.43$

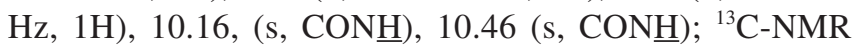
$\left(\mathrm{DMSO}-d_{6}\right): \delta$ (ppm) $51.4,119.2,120.2,121.7,121.8,123.5$, $128,128.2,131.5,137.7,137.9,152.9,166.4$.

Methyl 2-(p-tolylcarbamoyl)phenylcarbamate (4b): The product was obtained as a white crystal, m.p.:168-170 ${ }^{\circ} \mathrm{C}$; yield: $40 \%(\operatorname{method} \mathrm{A}) ; 70 \%(\operatorname{method} \mathrm{B})\left(\mathrm{lit}^{43} \mathrm{~m}\right.$.p. $172{ }^{\circ} \mathrm{C}$; yield $76 \%)$. IR $\left(\mathrm{KBr}, \mathrm{v}_{\max }, \mathrm{cm}^{-1}\right): 3335,3249(\mathrm{NH}), 1709$, 1656, $1602(\mathrm{C}=\mathrm{O}) .{ }^{1} \mathrm{H}-\mathrm{NMR}\left(\mathrm{DMSO}-d_{6}\right): \delta(\mathrm{ppm}) 2.29(\mathrm{~s}, 3 \mathrm{H}$, $\left.\mathrm{C}_{3}\right), 3.66\left(\mathrm{~s}, 3 \mathrm{H}, \mathrm{COOC} \underline{H}_{3}\right), 7.16-7.21(\mathrm{~m}, 3 \mathrm{H}), 7.55(\mathrm{t}, J=$ $8.04 \mathrm{~Hz}, 1 \mathrm{H}), 7.60$ (d, $J=8.04 \mathrm{~Hz}, 2 \mathrm{H}), 7.82$ (d, $J=7.36 \mathrm{~Hz}$, $1 \mathrm{H}), 8.09$ (d, $J=8.08 \mathrm{~Hz}, 1 \mathrm{H}), 10.25$ (s, CON$\underline{\mathrm{H}}), 10.40$ (s, $\mathrm{CON} \underline{\mathrm{H}}$ ); ${ }^{13} \mathrm{C}-\mathrm{NMR}$ (DMSO- $\left.d_{6}\right): \delta$ (ppm) 21.1, 52.6, 120.2, 121.4, 122.8, 129.34, 129.6, 132.7, 133.8, 136.6, 139.0, 154.1, 167.5 .
Methyl 2-(4-bromophenylcarbamoyl)phenylcarbamate (4c): The product was obtained as a white crystal, m.p.: 190$192{ }^{\circ} \mathrm{C}$; yield: $58 \%(\operatorname{method} \mathrm{A}) ; 80 \%(\operatorname{method} \mathrm{B}) .\left(\right.$ lit. $^{43} \mathrm{~m} . \mathrm{p}$. $198{ }^{\circ} \mathrm{C}$; yield $\left.95 \%\right)$. IR ( $\left.\mathrm{KBr}, \mathrm{v}_{\max }, \mathrm{cm}^{-1}\right): 3295,3192(\mathrm{NH})$, 1717, 1659, $1591(\mathrm{C}=\mathrm{O}) .{ }^{1} \mathrm{H}-\mathrm{NMR}$ (DMSO- $\left.d_{6}\right): \delta(\mathrm{ppm}) 3.65$ $\left(\mathrm{s}, 3 \mathrm{H}, \mathrm{COOC} \underline{H}_{3}\right), 7.20(\mathrm{t}, J=8.04 \mathrm{~Hz}, 1 \mathrm{H}), 7.54-7.56(\mathrm{~m}$, $3 \mathrm{H}), 7.70(\mathrm{~d}, J=8.8 \mathrm{~Hz}, 2 \mathrm{H}), 7.80(\mathrm{~d}, J=8.04 \mathrm{~Hz}, 1 \mathrm{H}), 8.03$ $(\mathrm{d}, J=8.08 \mathrm{~Hz}, 1 \mathrm{H}), 10.08(\mathrm{~s}, \mathrm{CON} \underline{\mathrm{H}}), 10.55$ (s, CONH$) ;{ }^{13} \mathrm{C}-$ NMR (DMSO- $\left.d_{6}\right): \delta(\mathrm{ppm}) 52.6,116.4,120.7,123.1,123.3$, $129.3,129.5,132.1,132.8,138.6,138.8,154.1,167.7$ (CONH).

Methyl 2-(4-methoxyphenylcarbamoyl)phenylcarbamate (4d): The product was obtained as a white crystal, m.p.:172-174 ${ }^{\circ}$; yield: $80 \%(\operatorname{method} A) ; 90 \%(\operatorname{method} B)$. IR (KBr, $\left.v_{\max }, \mathrm{cm}^{-1}\right): 3306,3100(\mathrm{NH}), 1714,1649,1603$ $(\mathrm{C}=\mathrm{O}) .{ }^{1} \mathrm{H}-\mathrm{NMR}$ (DMSO- $\left.d_{6}\right): \delta(\mathrm{ppm}) 3.46$ (s, 3H, $\left.\mathrm{OCH}_{3}\right)$, $3.70\left(\mathrm{~s}, 3 \mathrm{H}, \mathrm{COOC} \underline{\mathrm{H}}_{3}\right), 6.93(\mathrm{~d}, J=9.15, \mathrm{~Hz}, 2 \mathrm{H}), 7.11(\mathrm{t}, J=$ $7.8 \mathrm{~Hz}, 1 \mathrm{H}), 7.53(\mathrm{t}, J=7,8 \mathrm{~Hz}, 1 \mathrm{H}),, 7.61(\mathrm{~d}, J=9.15 \mathrm{~Hz}$, $2 \mathrm{H}), 7.82(\mathrm{~d}, J=7 \mathrm{~Hz}, 1 \mathrm{H}), 8.10(\mathrm{~d}, J=8 \mathrm{~Hz}, 1 \mathrm{H}), 10.36$ (s, CONH) $;{ }^{13} \mathrm{C}-\mathrm{NMR}$ (DMSO- $d_{6}$ ): $\delta$ (ppm ) 20.1, 54.7, 113.3, 119.0, 121.4, 121.7, 122.1, 128.2, 1301.0, 131.6, 138.1, 153.0, $155.5,166.3$.

General procedure for synthesis of 5a-d: A mixture of (4a-d) $(0.1 \mathrm{~mol})$ and hydrazine hydrate $(99 \%, 0.4 \mathrm{~mol})$ in absolute ethanol $(10 \mathrm{~mL})$ was subjected to microwave irradiation at $80{ }^{\circ} \mathrm{C} / 400$ watts for $2 \mathrm{~min}$. After completion of the reaction mixture the crude product was treated with hot ethanol to afford the pure products $\mathbf{5}$ a-d.

N-[2-(Phenylcarbamoyl)phenyl]hydrazinecarboxamide (5a): The product was obtained as a white powder, m.p.: 200-202 ${ }^{\circ}$; yield $99 \%$. IR (KBr, $\left.v_{\max }, \mathrm{cm}^{-1}\right): 3323,3187$ $(\mathrm{NH}), 1726,1646,1591(\mathrm{C}=\mathrm{O}) .{ }^{1} \mathrm{H}-\mathrm{NMR}\left(\mathrm{DMSO}-d_{6}\right): \delta(\mathrm{ppm})$ $5.50\left(\mathrm{~s}, 2 \mathrm{H}, \mathrm{NH}_{2}\right), 7.19-7.23(\mathrm{~m}, 7 \mathrm{H}), 7.65(\mathrm{t}, J=7.32 \mathrm{~Hz}$, 1H,), 7.94 (d, $J=7.36 \mathrm{~Hz}, 1 \mathrm{H}), 11.06$ (s, CON$\underline{\mathrm{H}}) ;{ }^{13} \mathrm{C}-\mathrm{NMR}$ $\left(\mathrm{DMSO}-d_{6}\right): \delta$ (ppm) 113.9, 115.7, 115.9, 123.0, 123.2, 127.4, $127.5,135,135.1,138.7,149.0,159.7$. Anal. calcd for $\mathrm{C}_{14} \mathrm{H}_{14} \mathrm{~N}_{4} \mathrm{O}_{2}$ : C, 62.21; H, 5.22; N, 20.73. Found: C, 62.50; H, 5.29; N, 20.94.

N-[2-(p-Tolylcarbamoyl)phenyl]hydrazinecarboxamide (5b): The product was obtained as a white powder, m.p.: $260-262{ }^{\circ} \mathrm{C}$; yield $80 \%$. IR (KBr, $\left.v_{\max }, \mathrm{cm}^{-1}\right): 3324,3128$ (NH), 1728, 1660, $1613(\mathrm{C}=\mathrm{O}) .{ }^{1} \mathrm{H}-\mathrm{NMR}\left(\mathrm{DMSO}-d_{6}\right): \delta(\mathrm{ppm})$ 2.37 (s, 3H, $\left.\mathrm{CH}_{3}\right), 7.18(\mathrm{~d}, J=8.08 \mathrm{~Hz}, 2 \mathrm{H}) 7.21-7.24(\mathrm{~m}$, $2 \mathrm{H}), 7.55(\mathrm{t}, J=7.36,8.04 \mathrm{~Hz}, 1 \mathrm{H}), 7.28(\mathrm{~d}, J=8.04 \mathrm{~Hz}, 2 \mathrm{H})$, 7.70 (t, $J=8.0 \mathrm{~Hz}, 1 \mathrm{H}), 7.93(\mathrm{~d}, J=8.08 \mathrm{~Hz}, 1 \mathrm{H}), 11.54$ (s, CONH) ${ }^{13} \mathrm{C}-\mathrm{NMR}$ (DMSO- $d_{6}$ ): $\delta$ (ppm) 21.3, 114.9, 115.5, 123.0, 128.1, 129.3, 129.9, 133.6, 135.7, 138.0,140.4, 150.8, 162.8. Anal. Calcd for $\mathrm{C}_{15} \mathrm{H}_{16} \mathrm{~N}_{4} \mathrm{O}_{2}$ : C, 63.37; H, 5.67; N, 19.71 . Found: C, 63.66; H, 5.80; N, 19.96.

N-[2-(4-Bromophenylcarbamoyl)phenyl]hydrazinecarboxamide (5c): The product was obtained as a white powder, m.p.: $278-280{ }^{\circ} \mathrm{C}$; yield $82 \%$. IR $\left(\mathrm{KBr}, \mathrm{v}_{\max }, \mathrm{cm}^{-1}\right)$ : $3427(\mathrm{NH}), 1722,1620.9(\mathrm{C}=\mathrm{O}) .{ }^{1} \mathrm{H}-\mathrm{NMR}$ (DMSO- $\left.d_{6}\right): \delta$ (ppm) 7.22-7.25 (m, 2H), 7.32 (d, $J=8.04 \mathrm{~Hz}, 2 \mathrm{H}), 7.68-7.73$ $(\mathrm{m}, 3 \mathrm{H}), 7.94(\mathrm{~d}, J=8.08 \mathrm{~Hz}, 1 \mathrm{H}), 11.58(\mathrm{~s}, \mathrm{CONH}) ;{ }^{13} \mathrm{C}-\mathrm{NMR}$ (DMSO-d $d_{6}$ : $\delta$ (ppm) 115.8, 118.5, 121.8, 123.1, 128.13, 132.0, 132.4, 135.7, 135.8, 140.4, 150.6, 162.7. Anal. Calcd for $\mathrm{C}_{14} \mathrm{H}_{13} \mathrm{~N}_{4} \mathrm{O}_{2} \mathrm{Br}$ (349: C, 48.16; H, 3.75; N, 16.05. Found: C, 48.00; H, 3.86; N, 16.32 
N-[2-(4-Methoxyphenylcarbamoyl)phenyl]hydrazinecarboxamide (5d): The product was obtained as a white powder, m.p.: $280-282{ }^{\circ} \mathrm{C}$; in yield $99 \%$. IR $\left(\mathrm{KBr}, \mathrm{v}_{\max }, \mathrm{cm}^{-1}\right)$ : 3471, $3420(\mathrm{NH}), 1731,1652(\mathrm{C}=\mathrm{O}) .{ }^{1} \mathrm{H}-\mathrm{NMR}$ (DMSO- $\left.d_{6}\right)$ : $\delta(\mathrm{ppm}) 3.80\left(\mathrm{~s}, 3 \mathrm{H}, \mathrm{OCH}_{3}\right), 7.00(\mathrm{~d}, J=8.79 \mathrm{~Hz}, 2 \mathrm{H}), 7.20-$ $7.23(\mathrm{~m}, 4 \mathrm{H}), 7.69(\mathrm{t}, J=8.15,1 \mathrm{H}), 7.93(\mathrm{~d}, J=8.07 \mathrm{~Hz}, 1 \mathrm{H})$; ${ }^{13} \mathrm{C}-\mathrm{NMR}$ (DMSO- $\left.d_{6}\right): \delta(\mathrm{ppm}) 54.8,113.5,113.8,114.6$, 122.0, 127.0, 127.8, 129.6, 134.5, 139.2, 149.8, 158.1. Anal. Calcd for $\mathrm{C}_{15} \mathrm{H}_{16} \mathrm{~N}_{4} \mathrm{O}_{3}: \mathrm{C}, 59.99 ; \mathrm{H}, 5.37 ; \mathrm{N}, 18.66$. Found: $\mathrm{C}$, $60.15 ; \mathrm{H}, 5.50 ; \mathrm{N}, 18.89$.

\section{Antimicrobial assessment}

Tested-microbial pathogens: The antimicrobial activities of 3a-d, 4a-d and 5a-d were assessed and biologically evaluated against five pathogenic bacterial species: Grampositive; S. pyogenes ATCC 19615 and S. aureus ATCC 25923 and Gram-negative; S. typhi ATCC 6539, K. pneumoniae ATCC 700603 and Pseudomonas aeruginosa ATCC 27853 and three pathogenic fungi; A. flavus, A. niger and C. albicans strain ATCC 90028 for antifungal activities.

Source of microbial pathogens: All standard strains of the evaluated pathogenic microbes (bacteria and fungi) were obtained from College of Science, Botany and Microbiology Dept., Research Central Laboratory. King Saud University, Saudi Arabia.

Preparation of microbial inoculums: The pathogenic microbes were pre-cultured in nutrient broth overnight in a rotary shaker for $24 \mathrm{~h}$ at $37 \pm 1{ }^{\circ} \mathrm{C}$. Then the cultures were centrifuged at 10,000 rpm for $5 \mathrm{~min}$ and the pellets were suspended in distilled water and the cell optical density (OD) was standardized spectrophotometrically (A570 nm). The purity of the cultures was checked after $8 \mathrm{~h}$ of incubation after cultivation and enriched again to ensure the cultural purity. After $24 \mathrm{~h}$ of incubation, microbial culture suspension was diluted with sterile Brain Heart Infusion medium (BHI) as a physiological solution broth. About $100 \mu \mathrm{L}$ of $10^{9} \mathrm{CFU} / \mathrm{mL}$ from the tested fungal strains i.e., A. flavus, A. niger and $C$. albicans were seeded into respective medium by spreading method technique.

For the bacterial strains i.e., S. pyogenes and S. aureus and Gram-negative; S. typhi, K. pneumonia and P. aeruginos; the bacterial suspension $\left(5 \times 10^{5} \mathrm{CFU} / \mathrm{mL}\right)$ was spread over the $90 \mathrm{~mm}$ petri dishes containing Mueller Hinton agar using a sterile cotton swab. Microbial screening for antimicrobial efficacy of the evaluated compounds

For the preparation of test solutions and antimicrobial assay using disk diffusion method: Test solutions were prepared by dissolving $100 \mathrm{mg}$ of each of the 3a-d, 4a-d and 5a-d in $1 \mathrm{~mL}$ of dimethyl sulfoxide to achieve a stock concentration of $100 \mathrm{mg} / \mathrm{mL}$ solution of test sample. Serial dilution was carried out to prepare $100 \mu \mathrm{g} / \mathrm{mL}$ of each compound. The dilution was carried out using dimethyl sulfoxide (General laboratory grade solvents purchased from supplied by Sigma Aldrich Chemicals Co. Ltd). Antimicrobial activities of the evaluated compounds 3a-d, 4a-d and 5a-d were tested against the microbial pathogens. Paper disc (6 mm diameter) was placed gently onto the tested microorganism-seeded plates after dipping with each compound. The antibacterial assay plates were incubated at $24 \mathrm{~h}$ at $37 \pm 1{ }^{\circ} \mathrm{C}$ h afterwards; the diameters of the inhibition zones were expressed and measured in $\mathrm{mm}$.

Minimum inhibitory concentration (MIC): The concentrations of each evaluated compound of 3a-d, 4a-d and 5a-d was prepared and diluted with DMSO as an organic solvent in range of 10 to $40 \mu \mathrm{g}$ per paper disc which were obtained by half-fold serial dilutions. Then they were used for MIC determination using method of disc diffusion method. Inhibitory test was carried out as described by Rasadah and Muharnad ${ }^{53}$. In this extent, the nutrient agar and sabouraud agar medium were inoculated with freshly prepared cells of $C$. albicans. The discs were dipped into the DMSO containing each compound and placed on the plates at concentrations 10, 15, $20,30,40 \mu \mathrm{g}$ per paper disc. Then the discs were put gently onto the surface of the petri dishes after the bacterial growth and evaporation of DEMSO. Zero concentration was considered as a negative control with the solvent only were maintained and kept parallel to monitor the changes. After the incubation of the petri dishes containing microbes at $37{ }^{\circ} \mathrm{C}$ for $24 \mathrm{~h}$, the antifungal and antibacterial activity was monitored and measured as a diameter of the inhibition zone formed around the disc. Each assay in this experiment was repeated three times and the results ( $\mathrm{mm}$ of zone of inhibition) were expressed as an average values.

Scanning electron microscopy (SEM): Fungal culture were prepared for scanning electron microscopy (SEM) according to the initial fixation and dehydration steps previously published by Hayat ${ }^{54}$. After the antimicrobial tests, the shape of the cells was examined using scanning electron microscopy. The cells were fixed at $24{ }^{\circ} \mathrm{C}$ for 60 min with $2.5 \%$ glutaraldehyde in $0.1 \mathrm{M}$ sodium cacodylate buffer ( $\mathrm{pH}$ 7.2) (SigmaAldrich ChemieGmbh, Steinheim, Germany), dehydrated with a serial concentration of ethanol and then dried on a critical point dryer (HCP-2; Hitachi Co.). The dried cell samples were coated with gold and examined using a scanning electron microscope (S-4100; Hitachi Co.). For transmission electron microscopy, dehydrated cells were embedded in a medium type LR white resin (Sigma Chemical Co., St. Louis, Mo.), which was polymerized at $60{ }^{\circ} \mathrm{C}$ for $24 \mathrm{~h}$. Specimens were then viewed with the scanning electron microscope $e^{54,55}$.

Protein extraction of $\boldsymbol{C}$. albicans: To determine the influence of compounds $\mathbf{3 a - d}, \mathbf{4 a - d}$ and $\mathbf{5 a - d}$ on the protein profile of the pathogenic C. albicans, Czapek Dox broth medium and supplemented with $40 \mu \mathrm{g} / \mathrm{mL}$ of the evaluated compounds was prepared. The medium $\mathrm{pH}$ was adjusted to 6.5. The sterilized media were inoculated with $C$. albicans, $1 \mathrm{~mL}$ of spores suspension $3 \times 10^{7}$ spore $/ \mathrm{mL}$ used as inoculums, then incubated in rotary shaker operating at $150 \mathrm{rpm}$ at $30{ }^{\circ} \mathrm{C}$ for 7 days.

Total proteins from mycelia of $C$. albicans were extracted according to the method described by Natarajan et al. ${ }^{57}$ The mycelia grown from the same set of flasks at a particular time point were harvested. In this method (trichloroacetic acid [TCA]-Acetone or TA), originally developed for protein extraction for 2-D gel analysis the isolate proteins, $0.2 \mathrm{~g}$ grown mycelium was powdered in liquid nitrogen with a mortar and pestle and the powder was suspended in $10 \mathrm{~mL}$ of $10 \%$ (w/v) trichloroacetic acid in acetone containing $0.07 \%(\mathrm{v} / \mathrm{v}) 2-$ mercaptoethanol. The suspension was vortexed and incubated at $22{ }^{\circ} \mathrm{C}$ for $1 \mathrm{~h}$ with intermittent stirring. Total protein was 
recovered by centrifugation at $14000 \mathrm{rpm}$ for $20 \mathrm{~min}$ at $4{ }^{\circ} \mathrm{C}$. The pellet was washed with acetone containing $0.07 \%(\mathrm{v} / \mathrm{v})$ 2-mercaptoeth-anol, dried under vacuum for $0.5 \mathrm{~h}$ and resuspended in $1 \mathrm{~mL}$ of lysis buffer (9 M urea, $1 \%$ 3-[\{3-cholamidopropyl \} dimethylammonio]-1-propane sulfonate) (CHAPS), $1 \%(\mathrm{v} / \mathrm{v})$ immobilized $\mathrm{pH}$ gradient (IPG) buffer 4-7 or 6-11 (Amersham Biosciences, Piscataway, New Jersey) and $1 \%$ dithiothreitol (DTT)) by ultrasonication in an ice-cold water bath. Cell debris was removed by centrifugation at $14000 \mathrm{rpm}$ for $10 \mathrm{~min}$ at $4{ }^{\circ} \mathrm{C}$.

Efficacy of the evaluated compounds of protein concentration: The protein concentration in the crude extract of fungal culture was determined by a modified method of Bradford ${ }^{56}$, (BioRad protein assay) and by UV spectroscopy measurement at $280 \mathrm{~nm}$. The BioRad protein assay is based on the differential colour change of a dye (silver stain) in response to various protein concentrations. Protein standard solutions of bovine serum albumin (BSA) were prepared in the range of $1-25 \mu \mathrm{g} / \mathrm{mL}$. $0.2 \mathrm{~mL}$ of the concentrated BioRad dye was added to $0.8 \mathrm{~mL}$ of each of the protein solutions in sterile test tubes. The blank contained only the dye solution. After $15 \mathrm{~min}$ the absorbance of the samples was measured at $595 \mathrm{~nm}$. By using the standard curve the protein concentration in the samples was extrapolated. For a rough estimation of the protein concentration the UV-spectra of the samples were recorded between 200$350 \mathrm{~nm}$. Protein concentration was calculated according to the following equation:

Protein $(\mathrm{mg} / \mathrm{mL})=1.55$ A $280 \mathrm{~nm}-0.76$ A $260 \mathrm{~nm}$

Total soluble protein content: Measurement of fungal cells total soluble protein content was determined according to the method of Lowry et al. ${ }^{57}$ using bovine serum albumin as the standard. Bio-Rad protein assay was used to measure the total amount of soluble protein in a crude extract of C. albicans. Bio-Rad protein assay is a dye-binding assay based on the differential colour change of a dye in response to various concentrations of protein ${ }^{59}$. The principle behind this assay is the absorbance maximum for an acidic solution of Coomassie Brilliant Blue G-250 shifts from $465 \mathrm{~nm}$ to $595 \mathrm{~nm}$ when binding to protein occurs. To an appropriately diluted sample of $2 \mathrm{~mL}, 0.50 \mathrm{~mL}$ Bio-Rad protein reagent (filter before use) was added and mixed well on a vortex mixer. Afterwards, a period of $5 \mathrm{~min}$ to $1 \mathrm{~h}$, the sample was measured at the absorbance of $595 \mathrm{~nm}$. The control sample was reagent blank (containing $0.50 \mathrm{~mL}$ Bio-Rad protein reagent and $2 \mathrm{~mL}$ buffer). Known concentrations of bovine serum albumin are used as standards.

Total soluble cell ions: Measurement of fungal cells total soluble cell ions were determined according to the method described by Sambrook et al. ${ }^{58}$.

\section{RESULTS AND DISCUSSION}

The basic mechanism of the reaction was described by Criegee more than 50 years ago ${ }^{30}$. First the peracid attacks the carbonyl carbon, leading to a hemiperacetal (also known as the criegee intermediate) and then one of the adjacent carboncarbon bonds migrates to the perester oxygen, reforming the carbonyl with loss of a proton and cleavage of the $\mathrm{O}-\mathrm{O}$ bond (Scheme-I).

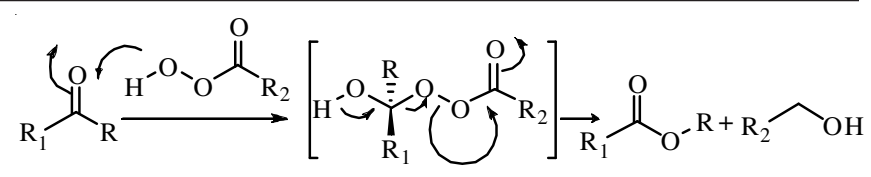

Scheme-I: Reaction mechanism of the oxidation of ketone by peroxycarboxylic acid

Isatin and its analogs are versatile substrates, which can be used for the synthesis of numerous biologically active compounds ${ }^{31}$. Isatin derivatives possess a broad range of biological and pharmacological properties and are widely used as starting materials for the synthesis of a broad range of heterocyclic compounds and as substrates for drug synthesis. Formerly, the study of isatin derivatives was connected with dye synthesis, but more recently these heterocycles have been shown to demonstrate antiprotozoal, antibacterial, antifungal, antiviral, anti-HIV, anticonvulsant, antitumoral, antiinflammatory and antihelminthic activities; influence neurodegenerative diseases; participate in metabolism; acetylcholinesterase inhibitors; and stimulate the growth of plants ${ }^{32-42}$.

Herein, four phenylcarbamic acid hydrazide and 2-[2-oxo3-(4-substituted phenylimino)indolin-1-yl] acetohydrazide derivatives were prepared from isatin's Schiff bases under microwave irradiation as well as conventional heating. All synthesized compounds were characterized and evaluated against Candida albicans strain for antifungal activities, Grampositive, Gram-negative (Salmonella typhi, Klebsiella pneumonia and Pseudomonas aeruginosa) and Aspergillus flavus, Aspergillus niger.

3-Substituted isatin (2a-d) were prepared under microwave irradiation (MWI), using a multimode reactor (Synthos 3000 Aton Paar, GmbH, 1400 W maximum magnetron) renders 2a-d from isatin in less reaction time, excellent yield and high purity, as observed from spectral data (IR, ${ }^{1} \mathrm{H} \mathrm{NMR}$ and ${ }^{13} \mathrm{C}$ NMR). This observation is consistent with data in the literature $^{42-46}$. Compounds 2a-d were subjected to react with ethyl chloroacetate using DMF as a solvent in the presence of $\mathrm{K}_{2} \mathrm{CO}_{3}$ under MWI as reported in the literature ${ }^{47}$; the crude ester was treated with hydrazine hydrate $(99 \%)$ in methanol under MWI for $2 \mathrm{~min}$ to afford the hydrazide derivatives 3a-d (SchemeII) in yield $64-81 \%$. The structures of the products were confirmed by spectral data.

Compounds 2a-d were also treated with a solution of $\mathrm{m}$ chloroperbenzoic acid ( $m$-CPBA) in $\mathrm{CH}_{3} \mathrm{OH}$ using the reported method $^{43}$ to afford the products 4a-d (Scheme-III). Compounds 4a-d were also prepared under microwave irradiation at $80{ }^{\circ} \mathrm{C} / 600$ Watts using $m$-CPBA in $\mathrm{CH}_{3} \mathrm{OH}$ to afford products 4a-d in less reaction time with higher yield and purity as observed from their spectral data. The products 4a-d were subjected to react with hydrazine hydrate under MWI at $60{ }^{\circ} \mathrm{C} /$ 400 Watts for 2 min to afford the desired products 5a-d in excellent yields (80-99 \%) (Scheme-III).

The antibacterial and antifungal activities of the compounds 3a-d, 4a-d and 5a-d were tested. All compounds did not exhibited any antibacterial activities against both tested Gram-positive and Gram-negative bacteria; antifungal activity against Aspergillus flavus, Aspergillus niger as well. These compounds exhibited promising antifungal activities particularly against the human pathogenic $C$. albicans (Fig. 1). The 
<smiles>O=C1Nc2ccccc2C1=O</smiles>

1

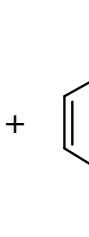

$\mathrm{R}$<smiles>[R]Cc1ccc(N)cc1[R]</smiles>

$\mathrm{R}=\mathrm{CH}_{3} ; \mathbf{b}$

$\mathrm{R}=\mathrm{Br} ; \mathbf{c}$

$\mathrm{R}=\mathrm{OCH}_{3} ; \mathbf{d}$<smiles>[R]c1ccc(/N=C2\C(=O)Nc3ccccc32)cc1</smiles>

2a-d<smiles>[R]c1ccc(/N=C2\C(=O)N(CC(=O)NN)c3ccccc32)cc1</smiles>

Scheme-II: 2-(2-Oxo-3-(4-substituted phenylimino)-indolin-1-yl)acetohydrazidederivatives 3a-d: Reaction conditions: (i) MWI/80 ${ }^{\circ} \mathrm{C} / 400 \mathrm{watts} / 2 \mathrm{~min}$. (ii) ethylchloroacetate/ $\mathrm{K}_{2} \mathrm{CO}_{3} /$ acetone/MWI/60 ${ }^{\circ} \mathrm{C} / 600$ watts/10 min. (iii) $\mathrm{NH}_{2} \mathrm{NH}_{2}(99 \%) / \mathrm{MeOH} / \mathrm{MWI} / 60^{\circ} \mathrm{C} / 400$ watts/2 min

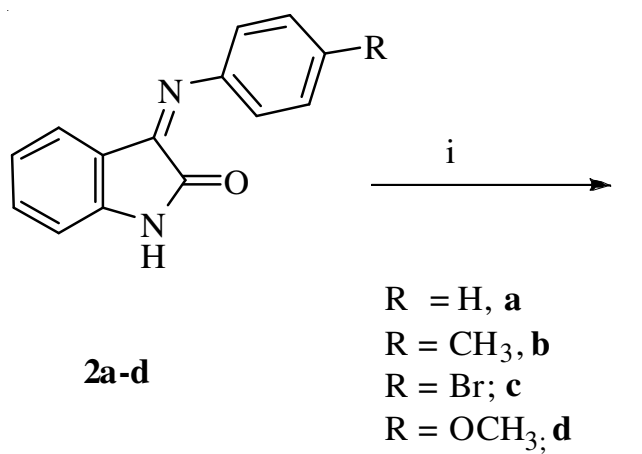

Scheme-III: Synthesis of phenylcarbamic acid derivatives. Reaction conditions: (i) m-CPBA in $\mathrm{CH}_{3} \mathrm{OH}$ at $0{ }^{\circ} \mathrm{C} 1 \mathrm{~h}$, r.t. $24 \mathrm{~h}$ or $\mathrm{MW} / 80^{\circ} \mathrm{C} / 600 \mathrm{Watts} / 5 \mathrm{~min}$. (ii) $\mathrm{NH}_{2} \mathrm{NH}_{2} / \mathrm{MeOH} / \mathrm{MW} / 60{ }^{\circ} \mathrm{C} / 400$ Watts $/ 2$ min

growth-inhibiting effects of 3a-d, 4a-d and 5a-d were quantitatively determined by using method of disc diffusion zone as shown in Fig. 1. The MIC values of the evaluated compounds were determined by using the broth dilution method. Results in Fig. (2) showed the minimum inhibitory concentration (MIC) was recorded 8, 7, 7, 7, 7, 7, 8, 7, 8, 6, 8, $7 \mathrm{~mm}$ for $\mathbf{3 b}$, 3a, 3d, 3c, 4c, 4b, 4a, 4d, 5d, 5a and 5b at $20 \mu \mathrm{g}$ per disc, respectively. Compound $\mathbf{5 c}$ represented an exception and recorded MIC at $15 \mu \mathrm{g}$ per disc $(9 \mathrm{~mm})$. All the tested compounds recorded no efficacy against the pathogenic C. albicans below $15 \mu \mathrm{g}$ per disc. From the revealed results, it was observed that compounds ( $\mathbf{3 b}, \mathbf{4 c}, \mathbf{5} \mathbf{c}$ and $\mathbf{5 a})$ possessed higher inhibitory effect on the pathogenic $C$. albicans due to their increasing space length between the bioactive groups and the compound backbone resulting in more released inhibitory groups Generally, the compounds samples killed $80-90 \%$ of

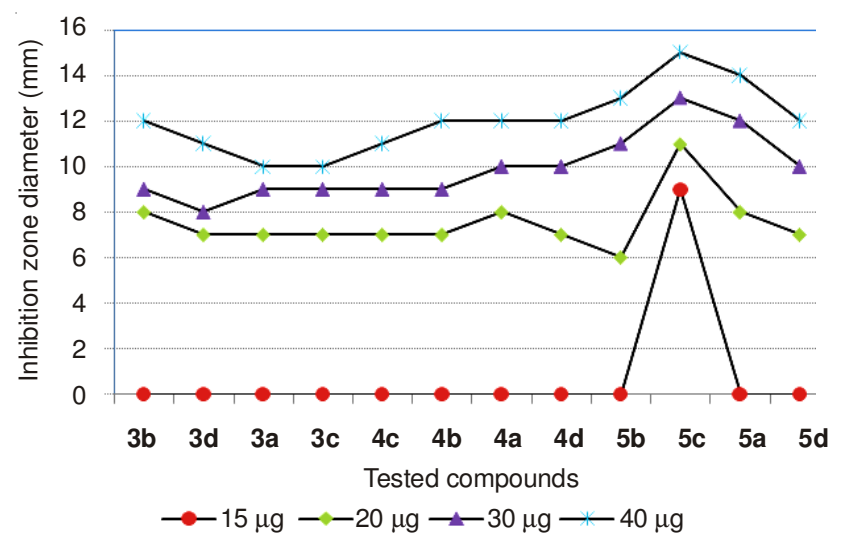

Fig. 1. Inhibition zones of $\mathbf{3 a - d}, \mathbf{4 a - d}$ and $\mathbf{5 a - d}$ at concentrations of $1=15$ $\mu \mathrm{g}$ per paper disc, $2=20 \mu \mathrm{g}$ per paper disc, $3=30 \mu \mathrm{g}$ per paper disc, $4=40 \mu \mathrm{g}$ per disc against $C$. albican
C. albicans at MIC concentration and the inhibitory effect varied slightly according to the compound microstructure after $24 \mathrm{~h}$ (Fig. 2). Our results are similar to the previous reported study among the compounds tested 5-chloro-3-(3',4'-dihydro2'-methylmercapto-4'-oxoquinazolin-3'-yl)-1-morpholino methyliminoisatin, which considered as the most active antimicrobial agent ${ }^{48}$.
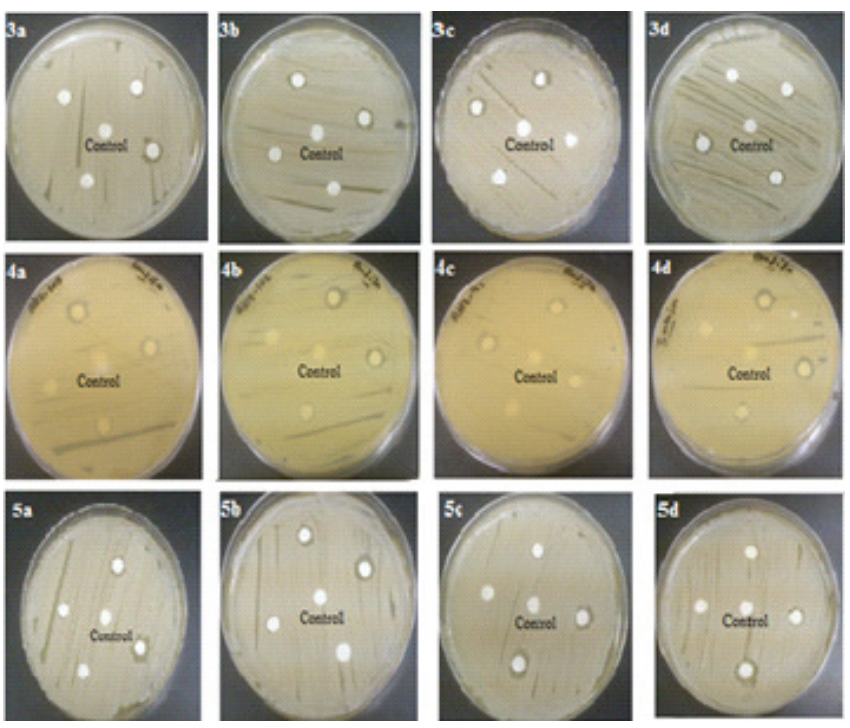

Fig. 2. MIC of different compounds and their derivatives on the pathogenic C. albicans

The results in Fig. 3 revealed that compounds $\mathbf{5 c}$ and $\mathbf{5 b}$ gave the highest inhibition percentage of total soluble cell ions (TSCI) estimated by 86.3 and $77.4 \%$, respectively, followed by $3 \mathrm{c}(69.3 \%), 4 \mathrm{c}(66 \%), 3 \mathrm{~b}(56.47 \%), 4 a(56.3 \%), 3 d$ 
$\mathbf{( 5 2 . 3 9} \%)$ and $\mathbf{5 a}, \mathbf{4 d}, \mathbf{4 b}$ and $\mathbf{5 d}$ were $50 \%$ and the least effect was recorded for $\mathbf{3 a}(18.82 \%)$. For total cell protein concentration (TCPC) the results showed that compounds $\mathbf{3 c}$ and $\mathbf{5 c}$ gave the highest inhibition percentage of (TCPC) estimated by 69.3 and $69.2 \%$, respectively, followed by $\mathbf{5 b}(56.89 \%)$, 3d $(60.02 \%), \mathbf{4 c}(52.8 \%), \mathbf{4 d}(50.83 \%)$ and for $\mathbf{4 b}, \mathbf{3 b}, \mathbf{5 a}$, $\mathbf{3 a}, \mathbf{5 d}$ and $\mathbf{4 a}$ were $50 \%$. The results proved strongly that the used compounds inhibited the protein synthesis production process in the pathogenic fungi $C$. albicans.

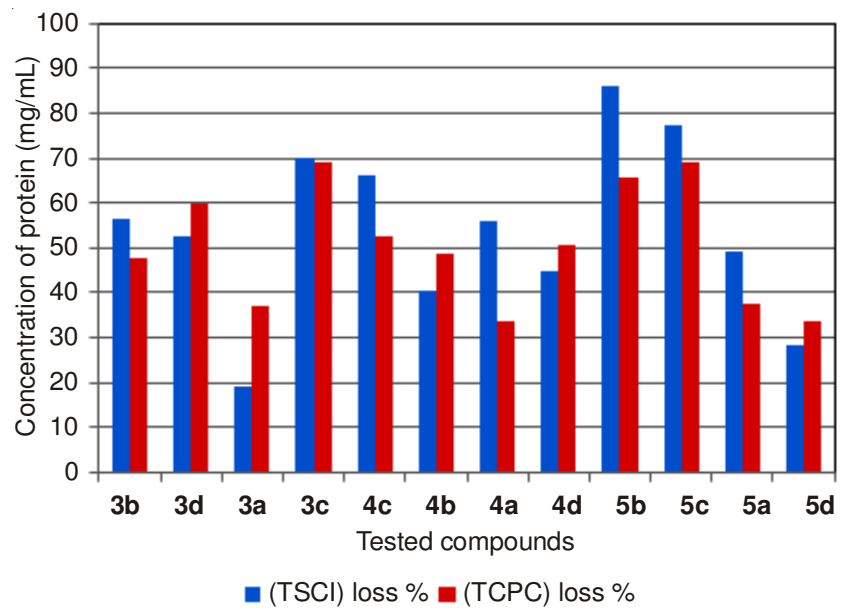

Fig. 3. Total soluble cell ions (TSCI) and total cell protein concentration (TCPC) $(\mathrm{mg} / \mathrm{mL})$

Abdel-Megeed ${ }^{49}$ reported that the antimicrobial agents affected greatly the protein synthesis process in fungi and did interfere with protein and nucleic acid synthesis of the tested fungus. Accordingly, it could be suggested that each type of antimicrobial agents have their own specific effect on certain metabolic activities of the sensitive fungal species. In general there was significant decrease in total soluble cell ions concentration and Total cell protein concentration (Fig. 4). This explained that the effect of the tested compounds on the total profile may reflex somehow protein inhibiting synthesis leading to the death of the cells occurred during the treatment of those evaluated compounds. Therefore, the alteration occurred protein profiles is considered a degree of tolerance that lead to cells malformation and destruction as a results of compounds treatment ${ }^{50-52}$.

In the present work the biological assessments explored by the disc diffusion method. Compounds 3a-d, 4a-d and 5a-d at concentrations $40 \mu \mathrm{g}$ per paper disc exhibited potential antifungal activity against the pathogenic fungi $C$. albicans. In general observation. There was highly potential pronounced activity against $C$. albicans. $C$. albicans cells examined by SEM were totally deformed and exhibited severe destruction (Fig. 4). The surfaces of the cells were totally damaged (4c, $\mathbf{3 b}$ and $\mathbf{5 b}$ ). Also, the intact cells had a smooth surface; while the most of the cell exhibited severe destruction is $\mathbf{5 c}$ (Fig. 4). For 5a-d, the cell of $C$. albicans surface became rough and swollen, the structure of the cell wall surface layer was wrinkled and round pores were partially deformed, indicating that the cytoplasmic structures were flushed out of the cells but they were unlysed. The results suggested that exposed cells of Candida albicans to each compound of 3a-d, 4a-d and 5a-d remained unlysed in the suspension at concentrations of $40 \mu \mathrm{g} / \mathrm{mL}$, particularly in some cases of the cells (3a, 3c and 4c) (Fig. 4).

It was found that intact cells had a smooth surface with overall intact morphology. For 3b, it was observed that many cells were enlarged, elongated and highly irregular. However, it was observed a pronounced deformation and visible shrinkage in case of $\mathbf{4 d}$ and this was mainly due to the binding of antimicrobial agents to the certain receptors of the fungal membrane that lead to the disruption of the cytoplasmic membrane and thus inhibits the growth (Fig. 4).

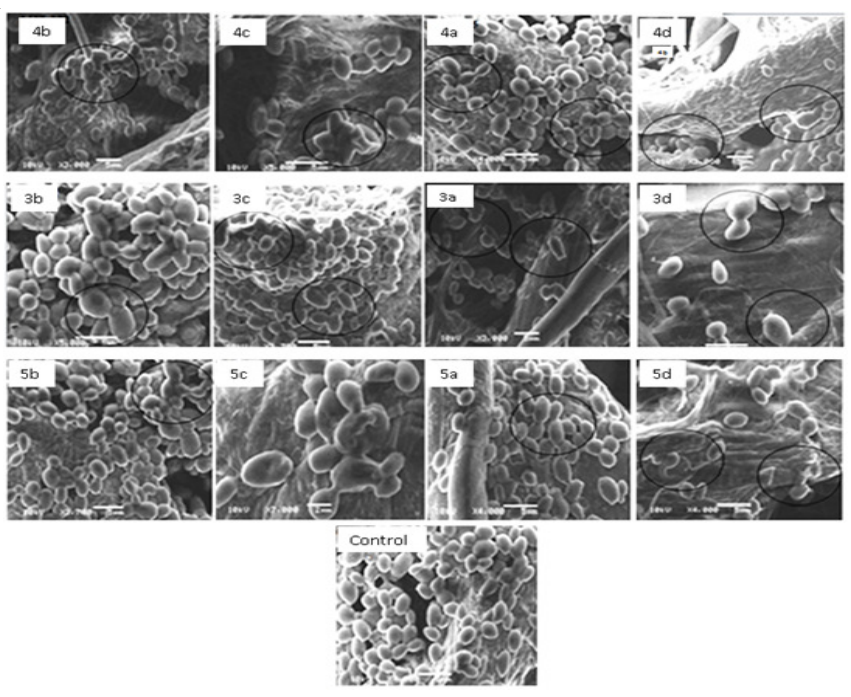

Fig. 4. Scanning electron micrograph of antimicrobial effects of $\mathbf{3 a - d}, \mathbf{4 a - d}$ and 5a-d at concentration $40 \mu \mathrm{g}$ per paper disc against $C$. albicans

\section{Conclusion}

In conclusion, we have demonstrated that microwave irradiation assisted the synthesis of phenylcarbamic acid derivatives (Baeyer-Villigeroxidation) in less reaction time, higher yield and purity than the conventional method. On the basis of present results, the synthesized compounds can be recommended as potentially effective alternative fungicides to protect the pathogenic Candida albicans and they should find a practical application as eco-friendly fungicides. Moreover, the results clearly indicate that the antifungal activity of the used compounds ascertain their values in the development of new anti-fungal agents to inhibit the growth of $C$. albicans. This unique antifungal efficacy of these compounds and their derivatives make a prime candidate for use in areas of medicine as a means to fight infection, in the food industry to prevent fungal contamination ${ }^{59}$. Thus, further test using these compounds is recommended on large number of bacterial and fungal strains to decide their potential as candidates in development of antibacterial drugs.

\section{ACKNOWLEDGEMENTS}

The authors extend their appreciation to the Deanship of Scientific Research at King Saud University for funding this work through research group project "RGP-234". 


\section{REFERENCES}

1. K.J. Ryan and C.G. Ray, Sherris Medical Microbiology, McGraw Hill, edn. 4 (2004); ISBN 0-8385-8529-9.

2. C. Enfert and B. Hube, Candida: Comparative and Functional Genomics, Caister Academic Press (2007); ISBN 978-1-904455-13-4.

3. Y. Zadik, S. Burnstein, E. Derazne, V. Sandler, C. Ianculovici and T. Halperin, Oral Dis., 16, 172 (2010).

4. T. Jones, N.A. Federspiel, H. Chibana, J. Dungan, S. Kalman, B.B. Magee, G. Newport, Y.R. Thorstenson, N. Agabian, P.T. Magee, R.W. Davis and S. Scherer, Proc. Natl. Acad. Sci. USA, 101, 7329 (2004).

5. B. Dizman, M.O. Elasri and L.J. Mathias, J. Appl. Polym. Sci., 94, 635 (2004).

6. T. Abel, J.I. Cohen, R. Engel, M. Filshtinskaya, A. Melkonian and K. Melkonian, Carbohydr. Res., 337, 2495 (2002).

7. M. Mirik, Y. Aysan and F. Sahin, Int. J. Agricult. Biol., 13, 203 (2011).

8. R. Nirmala, H.S. Kang, M.H. El-Newehy, R. Navamathavan, H.M. Park, H. Kim and Y. Human, J. Nanosci. Nanotechnol., 11, 4749 (2011).

9. J. Tung, R.K. Gupta, G.P. Simon, G.H. Edward and S.N. Bhattacharya, Polymer, 46, 10405 (2005).

10. C.Y. Xu, R. Inai, M. Kotaki and S. Ramakrishna, Biomaterials, 25, 877 (2004).

11. A.A. Mostafa, A.N. Al-Rahmah and A. Abdel-Megeed, J. Med. Plants Res., 5, 4231 (2011).

12. A. Baeyer and V. Villiger, Chem. Ber, 32, 3625 (1899).

13. M. Del Todesco Frisone, F. Pinna and G. Strukul, Organometallics, 12, 148 (1993).

14. G.-J. ten Brink, I.W.C.E. Arends and R.A. Sheldon, Chem. Rev., 104, 4105 (2004).

15. T. Uchida and T. Katsuki, Tetrahedron Lett., 42, 6911 (2001).

16. C. Bolm, G. Schlingloff and K. Weickhardt, Angew. Chem., 106, 1944 (1994).

17. C. Bolm, T. Khanh Luong and G. Schlingloff, Synlett, 1997, 1151 (1997).

18. K. Ito, A. Ishii, T. Kuroda and T. Katsuki, Synlett, 643 (2003).

19. A.V. Malkov, F. Friscourt, M. Bell, M.E. Swarbrick and P. Kocovský, J. Org. Chem., 73, 3996 (2008)

20. C. Paneghetti, R. Gavagnin, F. Pinna and G. Strukul, Organometallics, 18, 5057 (1999).

21. A. Watanabe, T. Uchida, R. Irie and T. Katsuki, Proc. Natl. Acad. Sci. USA, 101, 5737 (2004)

22. C. Bolm and O. Beckmann, Chirality, 12, 523 (2000).

23. K. Matsumoto, A. Watanabe, T. Uchida, K. Ogi and T. Katsuki, Tetrahedron Lett., 45, 2385 (2004).

24. C. Bolm, O. Beckmann, A. Cosp and C. Palazzi, Synlett, 2001, 1461 (2001).

25. J.C. Frison, C. Palazzi and C. Bolm, Tetrahedron, 62, 6700 (2006).

26. C. Bolm, O. Beckmann, T. Kühn, C. Palazzi, W. Adam, P.B. Rao and C.R. Saha-Möller, Tetrahedron Asymm., 12, 2441 (2001).

27. C. Bolm, O. Beckmann and C. Palazzi, Can. J. Chem., 79, 1593 (2001).

28. G.R. Krow, Org. React., 43, 251 (1993).

29. M. Renz and B. Meunier, Eur. J. Org. Chem., 1999, 737 (1999).

30. R. Criegee, Justus Liebigs Ann. Chem., 560, 127 (1948).
31. A.S. Ijaz, M.I. Choudhary, Z. Amtul and Atta-ur-Rehman, J. Chem. Soc. Pak., 19, 230 (1997).

32. M. Sarangapani and V.M. Reddy, Indian J. Pharm. Sci., 59, 105 (1997).

33. F.D. Popp, R. Parson and B.E. Donigan, J. Heterocycl. Chem., 17, 1329 (1980).

34. S.K. Bhattacharya, Indian J. Exp. Biol., 36, 118 (1998).

35. G.S. Singh, T. Singh and R. Lakhan, Indian J. Chem., 36B, 951 (1997).

36. A.M. Andreani, Boll. Chim. Farm., 116, 493 (1977).

37. A.E. Medvedev, A. Clow, M. Sandler and V. Glover, Biochem. Pharmacol., 52, 385 (1998).

38. V. Glover, J.M. Halket, P.J. Watkins, A. Clow, B.L. Goodwin and M. Sandier, J. Neurochem., 51, 656 (1988).

39. K.Waisser, K. Drazková , J. Cizmárik and K. Folia, J. Microbiol., 49, 265 (2004).

40. J. Azizian, M. Mehrdad, K. Jadidi and Y. Sarrafi, Tetrahedron Lett., 41, 5265 (2000).

41. A. Jarrahpour, D. Khalili, E. De Clercq, C. Salmi and J.M. Brunel, Molecules, 12, 1720 (2007).

42. S.K. Sridhar and A. Ramesh, Biol. Pharm. Bull., 24, 1149 (2001).

43. A. Gonzàlez, J. Quirante, J. Nieto, M.R. Almeida, M.J. Saraiva, A. Planas, G. Arsequell and G. Valencia, Bioorg. Med. Chem. Lett., 19, 5270 (2009).

44. M. Pandey, D.S. Raghuvanshi and K.N. Singh, J. Heterocycl. Chem., 46, 49 (2009)

45. S.K. Sridhar, M. Saravanan and A. Ramesh, Eur. J. Med. Chem., 36, 615 (2001).

46. R.S. Varma and P.K. Garg, J. Indian Chem. Soc., 58, 980 (1981)

47. B.S. Bari and A.O. Agrawal, Quart. J. Appl. Chem., 1, 34 (2008).

48. S.N. Pandeya, D. Sriram, G. Nath and E. De Clercq, Pharm. Acta Helv., 74, 11 (1999).

49. A. Abdel-Megeed, Dissertation, Psychrophilic Degradation of Long Chain Alkanes, Technische Universität Hamburg-Harburg, p. 156 (2004).

50. M. Osman, E.E.A. Elwy, I.M.K. Ismail and T.M.A. Abdel-Rahman, Bull. Fac. Sci. Cairo Univ., 57, 265 (1989).

51. M. Partoazar, M. Hoodaji and A. Tahmourespour, Afr. J. Biotechnol., 10, 19419 (2011).

52. A. Al-Arfaj and A. Abdel-Megeed, J. Pure Appl. Microbiol., 7, 1351 (2013).

53. M.A. Rasadah and Z. Muharnad, Prosid. PerubatanTraditional Malaysia Ke-5, Universiti Malaya, 173 (1988).

54. M.A. Hayat, Edward Arlond Lt., 1, 522 (1981).

55. S. Natarajan, C. Xu, T.J. Caperna and W.M. Garrett, Anal. Biochem., 342, 214 (2005).

56. M.M. Bradford, Anal. Biochem., 72, 248 (1976)

57. O.H. Lowry, N.J. Rosebrough, A.L. Farr and R.J. Randall, J. Biol. Chem., 193, 265 (1951).

58. J. Sambrook, E.F. Fritsch and T. Maniatis, Molecular Cloning: A Laboratory Manual, Cold Spring Harbor, Cold Spring Harbor Lab. Press, New York (1989).

59. E.-R. Kenawy, S.D. Worley and R. Broughton, Biomacromolecules, 8 , 1359 (2007). 